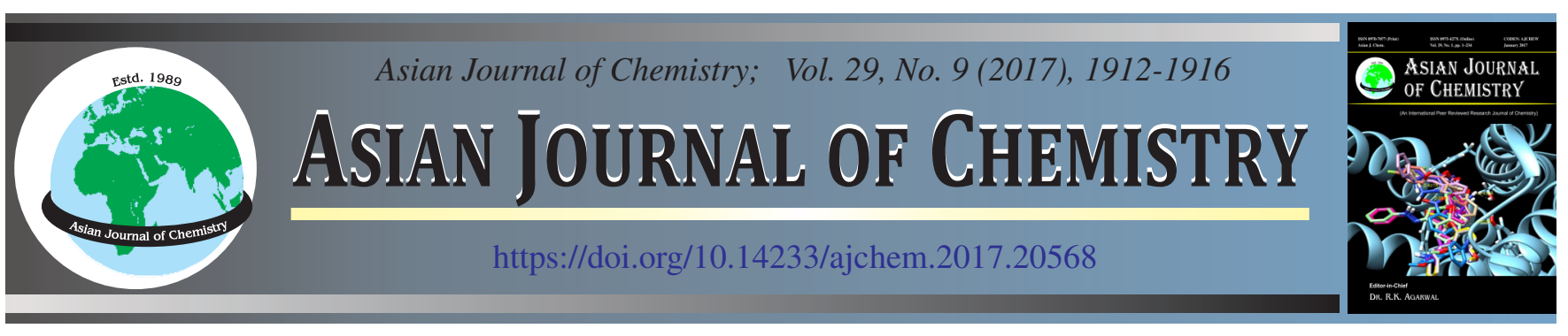

\title{
Synthesis and Characterization of Polyurethane Membrane from Nyamplung Seed Oils (Calophyllum inophillum)
}

\author{
Marlina, M. FARIDA and MustaniR*
}

Department of Chemistry, Faculty of Science, Syiah Kuala University, Banda Aceh 23111, Indonesia

*Corresponding author: Fax: +62 651 7551381; Tel: +62 651 7555264; E-mail: mustanir_yahya@ unsyiah.ac.id

\begin{abstract}
Nyamplung seeds (Calophyllum inophillum) oil was extracted by $n$-hexane using Soxhlet to obtain oil with yield of $55.55 \%$ (w/w). The product was yellowish green liquid having density of $0.88 \mathrm{~g} / \mathrm{mL}$. The iodine and hydroxyl numbers were $83.53 \mathrm{mg}$ iod/g and $64.29 \mathrm{mg}$ $\mathrm{KOH} / \mathrm{g}$, respectively. The results showed that Nyamplung seeds oil could be used as raw materials for synthesis of polyurethane membrane. Polyurethane membranes were synthesized through reacting Nyamplung seed oils with 1,6-hexamethylene diisocyanate by crosslink method. The reaction parameters of polyurethane membrane with ratio Nyamplung seed oils to the HMDI 5:7 (v/w), temperature polymerization at $95-100{ }^{\circ} \mathrm{C}$ during $60 \mathrm{~min}$. The membrane was cured at $150-155^{\circ} \mathrm{C}$ during $8 \mathrm{~h}$ gave the best rejection rate of $92.67 \%$ and flux $2.353 \mathrm{~L} / \mathrm{m}^{2} \mathrm{~h}$ bar gave optimum properties both visual and characterization. The characteristic of polyurethane membranes from Nyamplung seeds oils were transparent yellow, homogenous, hard, elastics and dried.
\end{abstract}

Keywords: Nyamplung seed oil, Hydroxyl number, Hexamethylene-1,6- diisocyanate, Polyurethane membrane.

\section{INTRODUCTION}

Preparation of membrane have been developed based on its raw materials whether from synthetic or natural resources. One kind of membrane synthesizing from natural resources is polyurethane membrane. Polyurethane is prepared by using raw material containing mono or polyhydroxyl group (-OH) [1]. Nicholson proposed that polyurethane is a thermoset polymer formed by reacting diisocyanate and polyfunctional compound containing hydroxyl group (polyol) [2]. Diisocyanate compound such as methylene-4,4-diphenyldiisocyanate (MDI), hexamethylene-1,6-diisocyanate (HMDI) and the mixture of toluene-2,4-diisocyanate with toluene-2,6-diisocyanate have been used for polyurethane synthesis [3].

Generally, polyurethane synthesis depends on the availability of petroleum due to polyol and isocyanate precusors, which are produced mostly from petroleum processing. Unfortunately, the petroleum has been declining significantly for decades, urging scientists to find alternative that is more available in nature. Vegetable oil is a promising raw material to synthesize product derivatives with many structural and functional variations [4].

One of seed-plant which is good to produce vegetable oil in comersing polyurethane and not used as food source, is Nyamplung (or bitangor) seed-plant (Callophylum inophylum). Nyamplung seeds potentially produce vegetable oil, especially riped seeds. The percentage of vegetable oil in Nyamplung seeds is high, around 40-73\% [5], The major content in Nyamplung seeds is oleate and linoleate [6-9]. This research used Nyamplung seeds in preparation of polyurethane membrane which was reacted with hexametylene-1,6-diisocyanate (HMDI composition was varied to possess the optimum membrane condition). In this research, the preparation and characterization of polyurethane membrane from Nyamplung seeds was studied.

Polyurethane membrane was produced and applied for water treatment which would remediate heavy metal waste from irresponsible gold mining activity in Krueng Sabee, Aceh Jaya Regency. In gold mining activity, mercury has been used to separate gold from stones. Waste consisting mercury was flowed to the stream by collectively which contaminated water stream even well water nearby. In 2013, Aceh Jaya Department of Health released a report related to mercury pollution in well water and artesian well water including water stream in Panga subdistict, Teunom, Krueng Sabee, Sampoiniet and Setia Bakti, stated that 78 water samples (62\%) from 125 samples have been proved containing mercury as pollutant.

\section{EXPERIMENTAL}

This research was conducted at Chemistry Department, Faculty of Mathematics and Natural Sciences, Syiah Kuala 
University, Banda Aceh. Raw materials were Nyamplung fruits (Calophyllum inophillum) originated from Ujong Pancu, Aceh Besar.

Apparatus used in this reasearch were glasses, thermometer, magnetic stirrer, hot plate, analytic balance, oven, Soxhlet, membrane module (rafted), atomic absorption spectrophotometry (AAS), Fourier transform infrared (FTIR), gas chromatography-mass spectrometry (GC-MS), scanning electron microscope-energy dispersive X-ray (SEM-EDX), differential thermal analysis (DTA) and tensile test.

Chemicals used were anhydrous $\mathrm{Na}_{2} \mathrm{SO}_{4}$, chloroform, distilled water, acetic acid, pyridine, phenolphthalein (pp), $\mathrm{KOH}$ $0.1 \mathrm{~N}, \mathrm{KI} 15 \%, \mathrm{Na}_{2} \mathrm{~S}_{2} \mathrm{O}_{3} 0.1 \mathrm{~N}$, Hanus solution, amilum indicator $1 \%, n$-hexane, 1,6-hexaemethylene diisocyanate (HMDI, Nyampung seeds oil (Callophylum inophylum), soil water from gold mining area, Gunong Ujeun Aceh Jaya, Aceh Province.

Extraction of Nyamplung seed oil: Nyamplung fruits used in this research were ripe and dry having black-brown shell. Nyamplung seeds were cleaned from the shells and dried for seven days until the colour has changed into red-brown. Last, Nyamplung seeds were milled into smooth and powder materials.

Nyamplung seed oil were extracted repeatedly by Soxhlet using $n$-hexane as extrator solvent at $80^{\circ} \mathrm{C}$. Then, crude extract containing Nyamplung seed oil was separated from the solvent by rotary evaporator $[5,7,10]$.

\section{Characterization of Nyamplung seed oil}

Iodine number: $10 \mathrm{~mL}$ chloroform and $30 \mathrm{~mL}$ Hanus solution were added into $0.03 \mathrm{~g}$ samples in an Erlenmeyer flask. The sample was kept in dark room for $30 \mathrm{~min}$. Then, 10 $\mathrm{mL} 15 \% \mathrm{KI}$ solution and $100 \mathrm{~mL}$ distilled water were added. The mixture was titrated by $0.1 \mathrm{~N} \mathrm{Na}_{2} \mathrm{~S}_{2} \mathrm{O}_{3}$ solution untils yellowish colour was obtained. 1-2 mL amilum solution was added then the titration was repeated by adding $\mathrm{Na}_{2} \mathrm{~S}_{2} \mathrm{O}_{3}$ solution $0.1 \mathrm{~N}$ until the mixture changed into clear liquid. The same procedure was applied for the control [11].

Hydroxyl numbers: $2 \mathrm{~g}$ of Nyamplung seed oil was added to $4 \mathrm{~mL}$ acetylation reagents, the mixtures were then heated to $98^{\circ} \mathrm{C}$ for $2 \mathrm{~h}$, the samples were cooled down to room temperature. $6 \mathrm{~mL}$ distilled water was added, the lid and the wall of glass were washed off. After $24 \mathrm{~h}$ storage, 3-4 drops of phenolphthalein indicator were added and followed by titration using $0.5 \mathrm{~N} \mathrm{KOH}$ solutions [11].

Oil composition analysis using Gas ChromatographyMass Spectrometry (GC-MS), GC2010 MSQP 2010S Shimadzu.

Preparation of polyurethane membrane: Polyurethane dope solution was prepared by reacting Nyamplung seed oil from extraction process with HMDI by using crosslink method. $5 \mathrm{~mL}$ Nyamplung seeds oil was used as -OH source and HMDI was used as -NCO source. Oil ratio to HMDI was varied 5:3, 5:5, 5:7 and 5:9 (v/w) with polimerization time of $60 \mathrm{~min}$ and polymerization temperature of $90-100{ }^{\circ} \mathrm{C}$. Dope solution was casted in petri dish and was given mark as a sign for membrane thickness, then cured by using oven at $150-155^{\circ} \mathrm{C}$ for $8 \mathrm{~h}$. The formed sheets were then exfoliated into flowing water by using spatula [12].

Characterization of polyurethane membrane: Membrane performance was evaluated by measuring flux value and rejection factors. Determination of those parameters based on dead end flow system nanofiltration modul by using membrane which produced at 10 bars. Surface of membrane was used $25.5 \times 10^{-4} \mathrm{~m}^{2}$ and filration time was $5 \mathrm{~min}$. Concentration of mercury in feedstock and permeat was determined by atomic absorption spectrophotometry (AAS) (Shimadzu AA-6300). Polyurethane membrane functional group was determined by using Fourier transform infrared (FTIR) (Agilent resolution pro cary 630 FTIR spectrometer). Thermal analysis was done by using differential thermal analysis (DTA) (SDT Q600). Mechanical test of polyurethane membrane was using tensile test, Computer Type Universal Testing Machines (ASTM D638).

Morphology analysis of membrane was performed using scanning electron microscopy-energy dispersive X-ray (SEMEDX) (Tabletop microscope 3000) at Materials Laboratory, Mechanical Engineering Department, Faculty of Engineering, UNSYIAH, Banda Aceh. Quantitative analysis of prepared polyurethane membrane was measured by using EDX (energy dispersion X-ray), which was attached to SEM.

\section{RESULTS AND DISCUSSION}

Extraction of Nyamplung seed oil: Nyamplung seeds were cleaned from the shells the dried for 7 days at room temperature until the colour has changed into red brown. After that, Nyamplung seeds were milled to obtain fine powder. $1 \mathrm{~kg}$ of dried Nyamplung fruit was equal to $600 \mathrm{~g}$ Nyamplung seeds after drying process, Nyamplung seeds weigh decreased to \pm $400 \mathrm{~g}$. Extraction of Nyamplung seeds oil was done by Soxhlet process using $n$-hexane solvent.

The averange yield of Nyamplung seed oil extraction was $55.55 \%$. The result was lower than the previous research [13] that reached $66.58 \%$. This was due to extraction time and the level of fruit's ripe. Geographical condition where the fruit has grown also influenced the yield of extraction [14]. Atabani and Cesar [5] explained Nyamplung seeds may contained oil around 40-73\% [5]. The as-prepared samples had greenyellowish liquid with the density of $0.88 \mathrm{~g} / \mathrm{mL}$.

Characterization of Nyamplung seed oil: Iodine numbers was used to determine the unsaturation of oil. Saturation of oil decreased with the increased of iodine numbers. Oil collection from extraction of Nyamplung seeds had iodine numbers around $83.53 \mathrm{mg} \mathrm{iod} / \mathrm{g}$ oil. The resulted iodine numbers latter was close to Hasibuan et al. [9]. High iodine numbers means that fatty acid containing in Nyamplung seeds oil mostly was unsaturated fatty acid.

Determination of hydroxyl group (-OH) was carried out to calculate the numbers of $\mathrm{OH}$ group inside Nyamplung seeds oil. The averange of $\mathrm{OH}$ numbers was $64,292 \mathrm{mg} \mathrm{KOH} / \mathrm{g}$. The high numbers of $\mathrm{OH}$ inside Nyamplung seeds oil was used to synthesize polyurethane membrane.

The result of GC-MS analysis showed extraction of Nyamplung seeds oil has 4 wide peaks (Fig. 1). Mass spectrum analysis with Nyamplung seed oil as chromatogram samples could be seen in Table-1. Peaks with retention time (tR) in Table-1 have mass spectrum which could be assumption basis in compound determination, specific at certain retention time. These results were compared to mass spectrum (MS) database to find high match of similarity index (SI) numbers [15]. Mass 
TABLE-1

RESULT OF CHROMATOG MASS SPECTRUM FROM NYAMPLUNG SEEDS OIL AS SAMPLES

\begin{tabular}{ccccl}
\hline $\begin{array}{c}\text { Peak } \\
\text { numbers }\end{array}$ & $\begin{array}{c}\text { Retention } \\
\text { time }(\mathrm{min})\end{array}$ & $\begin{array}{c}\text { Abundance } \\
(\%)\end{array}$ & \multicolumn{1}{c}{ Fragmentation $(\mathrm{m} / \mathrm{z})$} & \multicolumn{1}{c}{ Assumption compound (based on MS library) } \\
\hline 2 & 40.808 & 17.94 & $\begin{array}{l}270(\mathrm{M}+), 239,227,199,185,171,157,143, \\
129,115,101,87,74,57,41\end{array}$ & $\begin{array}{l}\text { Palmitate acid (Hexadecenoic acid, methyl } \\
\text { ester) }\end{array}$ \\
& 44.347 & 23.12 & $294(\mathrm{M}+), 150,136,109,95,81,67,41$ & $\begin{array}{l}\text { Linoleic acid }(9,12-H e x a d e c a d i e n o i c ~ a c i d, ~ \\
\text { methyl ester) }\end{array}$ \\
4 & 44.499 & 42.54 & $296(\mathrm{M}+), 264,222,180,123,98,74,69,56,41$ & $\begin{array}{l}\text { Oleic acid (11-Octadecenoic acid, methyl ester) } \\
\text { Stearic acid (Octadecanoic acid, methyl ester) }\end{array}$ \\
\hline
\end{tabular}

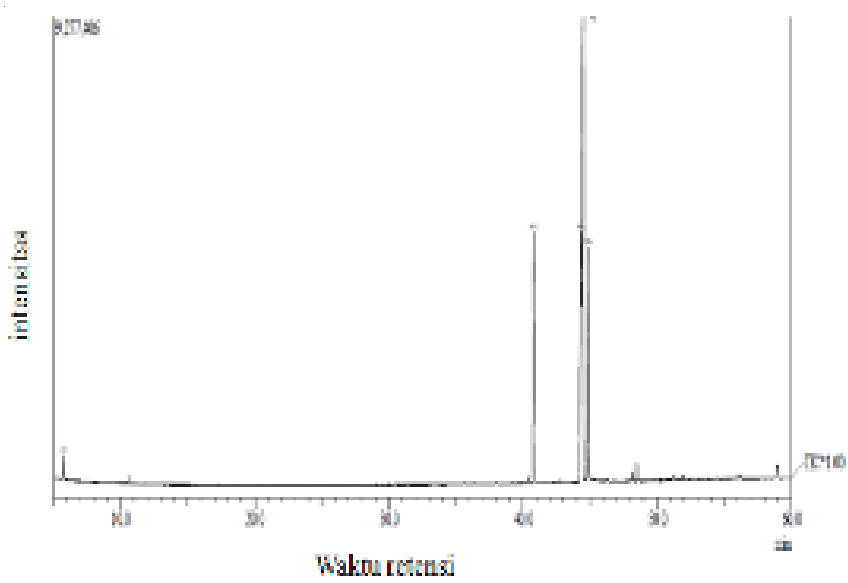

Fig. 1. Nyamplung seeds oil chromatogram

spectra of the samples and MS database of mass spectrum of the highest peak of retention time of GC chromatogram shown in Fig. 2.

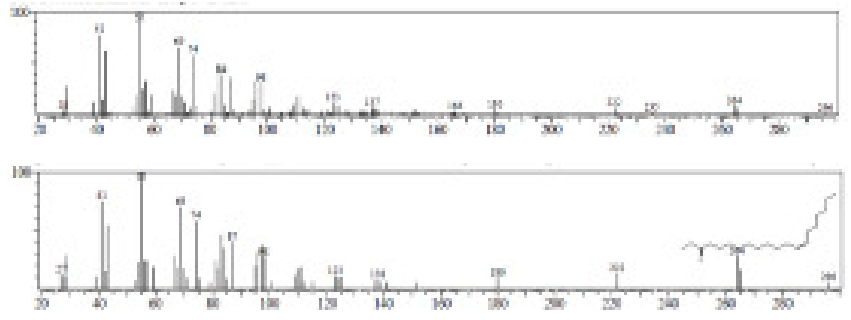

Fig. 2. Mass spectrum of desire compound peak no 4 and mass spectrum of data library 11-octadecenoic acid, methyl ester $(\mathrm{SI}=96)$

Oleic acid with mass $296 \mathrm{~m} / \mathrm{z}$ was the largest component in Nyamplung seed oil extraction having percentage of $42.54 \%$. This in accordance to previous research conducted [7-9].

Preparation of polyurethane membrane: In this research, HMDI variation was used to get an excellent membrane performance and good mechanical properties, whereas another factors such as time and polimerization temperature were constant. Preparation of polyurethane membrane was done by adjusting polymerization temperature at $95-100{ }^{\circ} \mathrm{C}$ for $60 \mathrm{~min}$, with the result that dope polyurethane solution had transparant yellow colour and slight thick. It was then molded into petri dish and cured for $8 \mathrm{~h}$ at $150-155^{\circ} \mathrm{C}$. Compositional ratio of Nyamplung seed oil to HMDI were $5: 3 ; 5: 5 ; 5: 6 ; 5: 7 ; 5: 9$ (v/w). Fig. 2 shows the comparation visual characteristic of membrane with HMDI composition variation.

$3 \mathrm{~g}$ and $5 \mathrm{~g}$ HMDI compositions produced undried polyurethane membrane, due to mostly Nyamplung seed oil did not react with -NCO (urethane bond did not form), whereas $9 \mathrm{~g}$ HMDI composition were not homogeneous and brittle due to concentration of isocyanate was excessive. The most attractive visual was reached with the comparation of oil and HMDI was 5:7 (v/w). Prepared polyurethane membrane from Nyamplung seeds oil was homogeneous, hard, elastic, dried, not brittle and transparant yellow (Fig. 3). Membranes with optimum visual condition were characterized by using FTIR, DTA, tensile test, SEM and membrane performance.

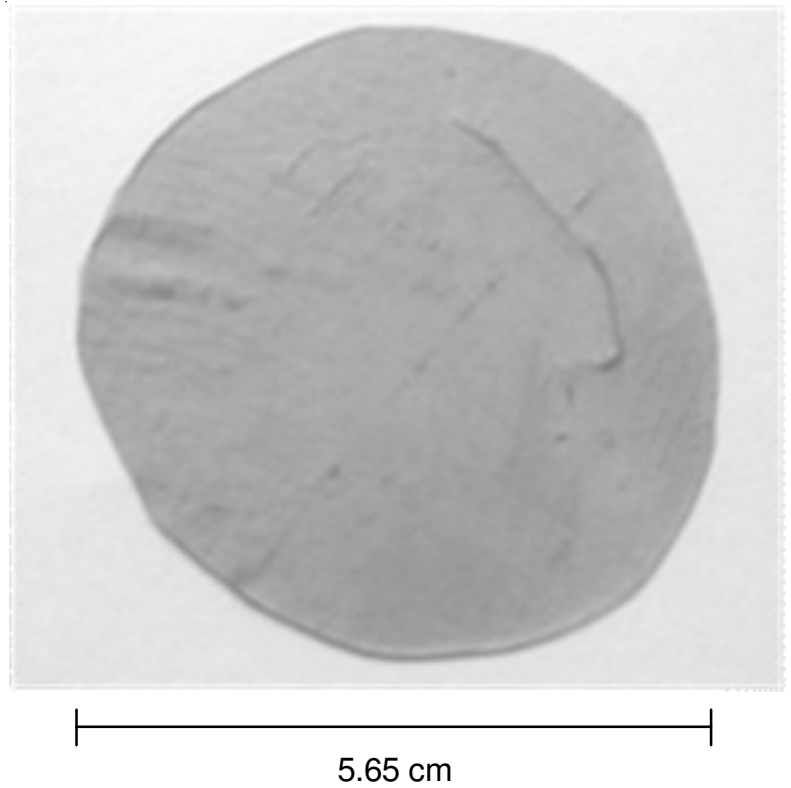

Fig. 3. Polyurethane membrane from myamplung seeds oil

\section{Characterization of polyurethane membrane}

Membrane performance: The results of flux and rejection factor from prepared samples were attained $2.353 \mathrm{~L} / \mathrm{m}^{2} \mathrm{~h}$ bar and $92.675 \%$, respectively for $5 \mathrm{~mL} \mathrm{MBN}$ and $7 \mathrm{~g}$ HMDI. The measurement was done by flowing the feedstock using dead end nanofiltration flow system module with pressure of 10 bar for $5 \mathrm{~min}$. The concentration of feedstock and well water permeate were measured by AAS. Bait was taken from soil water in Makmur Subdistrict, Aceh Jaya which had been contaminated by mercury with concentration of $18.8833 \mathrm{ppb}$, the gaining permeate showed mercury concentration was decreased to $1.3833 \mathrm{ppb}$ and rejection process was $92.675 \%$.

In this study, prepared membrane can be applied to nanofiltration separating process, which remove mercury contamination from water. Nanofiltration membrane permeability was 1.4-12 $\mathrm{L} \mathrm{m}^{-2} \mathrm{~h}^{-1}$ bar $^{-1}$ with pressure $10-35$ bar [16]. This flux was 
achived from Nyamplung seed oil membrane with pressure (10 bars) and was consider as nanofiltration membrane type.

Determination of polyurethane membrane functional group: Fig. 4 shows FTIR spectrum of polyurethane membrane from Nyamplung seeds. The effectiveness of the polymerization process of polyurethane membrane was showed by specific absorption $\mathrm{C}=\mathrm{O}$ urethane at $1742.268 \mathrm{~cm}^{-1}$. The formation of urethane bonding was demonstrated by the appearance of absorption from extended vibration of secondary N-H that was indicated by urethane binding process at $3308.852 \mathrm{~cm}^{-1}$ wavenumber. Absorption at $1458.289 \mathrm{~cm}^{-1}$ showed the existance of allofanate group in polyurethane membrane, allofanate nett formed by extended reaction between urethane group and excessive isocyanate which has not bind to $\mathrm{OH}$ group (forming urethane) by additon process involving nitrogen from urethane group [17]. The formation process of allofanate was using thermal energy, especially during curing stage [18]. The inexistence of free isocyanate group from both polyurethane membranes was proved by no absorption of -NCO group at $2300-2250 \mathrm{~cm}^{-1}$. This indicated that all isocyanate reacted to form urethane bonding.

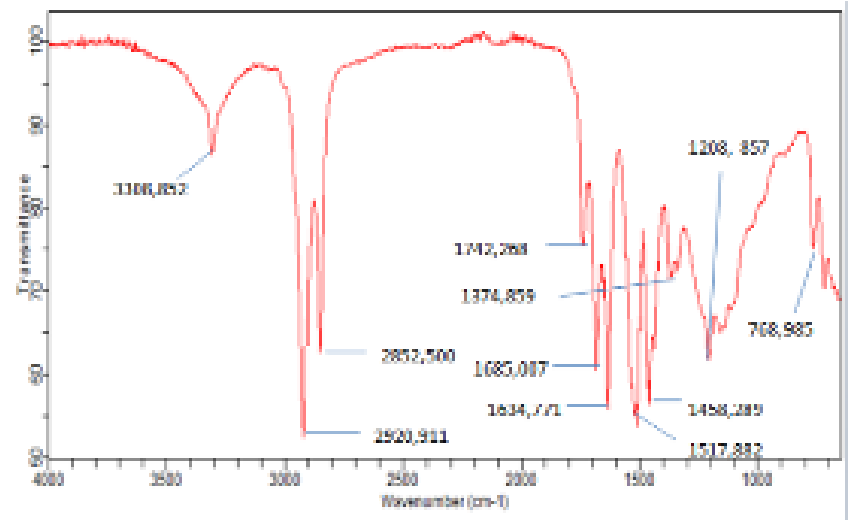

Fig. 4. FTIR spectrum of polyurethane membran from Nyamplung seed oil

Thermal analysis: Fig. 5 displays DTA thermogram to analyze the thermal behaviour of Nyamplung seed oil membrane. The data showed $\mathrm{T}_{\mathrm{g}}$ at $63{ }^{\circ} \mathrm{C}$ and $\mathrm{T}_{\mathrm{d}}$ at $471.84{ }^{\circ} \mathrm{C}$ with crystal contain of membrane was $5.988 \%$. Crystal percentage desribed the numbers of forming hard segment.

Mechanical analysis: Mechanical test of Nyamplung seed oil membrane was performed using tensil test (ASTM D638), Nyamplung seed oil membrane has tensile strength

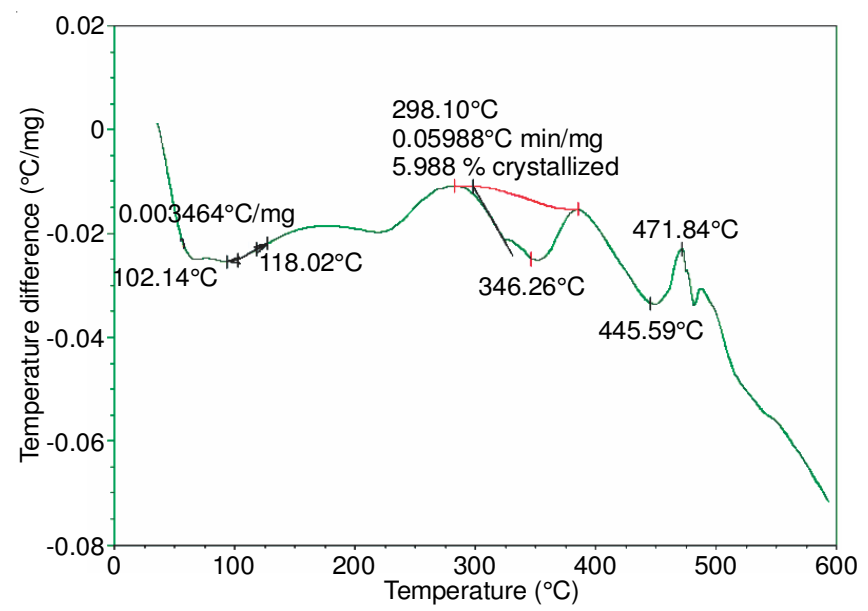

Fig. 5. DTA Thermogram polyurethane membrane from Nyamplung seed oil

of $1.28 \mathrm{kgf} / \mathrm{mm}^{2}$ and elongation of $53.77 \%$. That results indicated the prepared membrane was elastic and strong.

Morphology of membrane: Morphology analysis of membrane using scanning electron microscopy (SEM) can reveal the information related to structure of membrane [16]. Morphology structure of polyurethane membrane could be seen by cross section with magnification of 250x, 500x and 1000x (Fig. 6). Based on the result of SEM, the prepared membrane has closed structure, in additon that the flux value was small.

EDX analysis was showed in Fig. 7. EDX spectrum pointed out that the components composing polyurethane membrane were carbon $(47.82 \%)$, nitrogen $(41.61 \%)$ and oxygen $(10.58 \%)$.

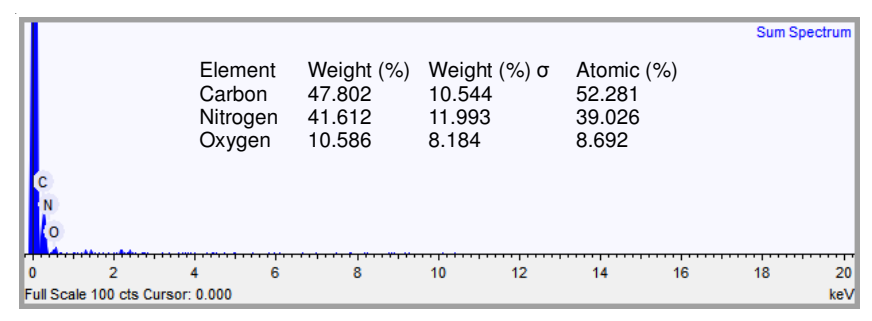

Fig. 7. Graphic EDX on SEM

\section{Conclusion}

Nyamplung seeds oil could be used as raw material for synthesis of polyurethane membrane by reacting with
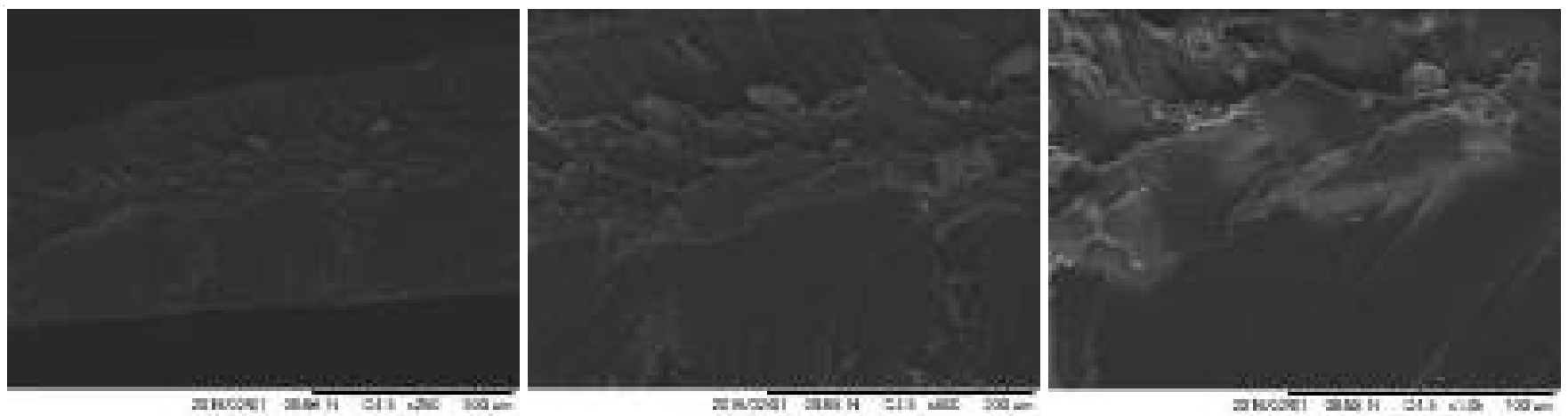

Fig. 6. Morphology of polyurethane membrane with magnification 250x, 500x, 1000x 
hexamethylene-1,6-diisocyanate (HMDI). Nyamplung seeds oil membrane with oil compositon to HMDI 5:7 (v/w) used temperature $95-100{ }^{\circ} \mathrm{C}$ and polymerization time $60 \mathrm{~min}$. Temperature of curing process was $150-155^{\circ} \mathrm{C}$ for $8 \mathrm{~h}$. The visual and characterization showed the optimum condition while flux value was $2.353 \mathrm{~L} / \mathrm{m}^{2} \mathrm{~h}$ bar and rejection factor was $92.67 \%$. Flux was achived from Nyamplung seed oil membrane with pressure (10 bars) that was considered as nanofiltration membrane type. Prepared polyurethane membrane from Nyamplung seed oil was homogeneous, hard, elastic, dried, not brittle and had transparant yellow colour.

\section{REFERENCES}

1. L.S. Ramanathan, S. Sivaran and K.M. Munmaya, Polyurethanes, Polymer Data Handbook, Oxford University Press Inc., USA, pp. 870-877 (1999).

2. J.W. Nicholson, The Chemistry of Polymer, Chambridge, UK (1997).

3. E. Rohaeti, J. Matematika dan Sains, 8, 63 (2003).

4. A.S. More, T. Lebarbé, L. Maisonneuve, B. Gadenne, C. Alfos and H. Cramail, Eur. Polym. J., 49, 823 (2013); https://doi.org/10.1016/j.eurpolymj.2012.12.013.

5. A.E. Atabani and A.S. César, Renew. Sustain. Energy Rev., 37, 644 (2014); https://doi.org/10.1016/j.rser.2014.05.037.

6. A. Sanjid, H.H. Masjuki, M.A. Kalam, S.M.A. Rahman, M.J. Abedin and S.M. Palash, Renew. Sustain. Energy Rev., 27, 664 (2013); https://doi.org/10.1016/j.rser.2013.07.059.

7. H.C. Ong, T.M.I. Mahlia, H.H. Masjuki and R.S. Norhasyima, Renew. Sustain. Energy Rev., 15, 3501 (2011); https://doi.org/10.1016/j.rser.2011.05.005.
8. A. Adewuyi, O.H. Fasusi and R.A. Oderinde, J. Acute Medicine, 4, 75 (2014); https://doi.org/10.1016/j.jacme.2014.02.001

9. S. Hasibuan, S. Sahirman and N.M.A. Yudawati, Agritech, 33, 311 (2013); https://doi.org/10.22146/agritech.9553.

10. R.S. Juwita and S. Rahmawati, Nyamplung Seed Oil Retrieval through Extraction Process as Alternative Fuels, In: Seminar on Final Duty of Chemical Engineering Department, Faculty of Engineering, Diponegoro University, Semarang, Central Java, Indonesia (2009).

11. N.M.S. Marlina, C.L. Radiman and S.A. Achmad, Synthesis of polyurethane Membrane from Oxidized Free Fatty Acid and Toluene Diisocyanate (TDI), Proceeding of Seminar MIPA IV, Institut Teknologi Bandung, Bandung, Indonesia (2004).

12. Marlina, J. Rekayasa Kimia dan Lingkungan, 6, 67 (2007).

13. D. Suhendra, A. Solehah, D. Asnawati and E.R. Gunawan, Chem. Progr., 6. 62 (2013).

14. M. Manzoor, F. Anwar, T. Iqbal and M.I. Bhanger, J. Am. Oil Chem. Soc., 84, 413 (2007) https://doi.org/10.1007/s11746-007-1055-3.

15. Hutami, R., 2012, Analisis Komponen Asam Lemak dalam Minyak Goreng dengan Instrumen GC-MS (Gas Chromatography-Mass Spectrometer), pascasarjana Institut Pertanian Bogor.

16. M. Mulder, Basic Principles of Membrane Technology, Kluwer Academic Publisher, Dordrecht, edn 2 (1996).

17. G.T. Howard, Int. Biodeterior. Biodegr., 49, 245 (2002); https://doi.org/10.1016/S0964-8305(02)00051-3.

18. E. Rohaeti and S. Senam, J. Penelitian Saintek, 15, 10 (2010). 